IJJM

Ilomata International Journal of Management

P-ISSN: 2714-8971; E-ISSN: 2714-8963

Vol. 1 No. 3 July 2020 pp.132-138

https://www.ilomata.org/index.php/ijim

\title{
The Effect of Return on Equity (ROE) and Earning per Share (EPS) on Stock Prices in Indonesia Stock Exchange 2015-2018
}

\author{
Herlina Lusiana \\ Management Study Program, Faculty of Economics \\ Kalimantan Islamic University Muhammad Arsyad Al Banjari Banjarmasin, Indonesia \\ Correspondent: lusiana.muyoto@gmail.com
}

Submitted : May 25, 2020 Revised : June 15, $2020 \quad$ Published : July 30, 2020

\begin{abstract}
This study aims to analyze the source of a company's profitability by choosing two main factors namely, Return on Equity (ROE) and Earning per Share (EPS) as the strength and resilience of companies engaged in food and beverage listed on the Indonesia Stock Exchange. This study uses time series data from 2015 to 2018. The dependent variable is the stock price. Meanwhile the independent variables are Return on Equity (ROE) and Earning per Share (EPS). The determination of the sample uses positive sampling, the sampling technique uses two special criteria from researchers. The first criterion, only food and beverage companies that publish financial statements in full during the period 2015 to 2018, and the second criterion, food and beverage companies that have financial statement data in accordance with the studied variables, namely Return on Equity (ROE) and Earning per Share (EPS). Samples that meet the criteria are 11 registered food and beverage companies on the Indonesia Stock Exchange for the period 2015 to 2018. Data analysis techniques using multiple linear regression with the help of the SPSS program. The findings show that Return on Equity (ROE) has a positive and significant impact on stock prices, while Earning per Share (EPS) has an impact negative and significant to stock prices. This finding confirms that strength the profitability of a company through Return on Equity (ROE) affects the stock prices of food and beverage companies in Indonesia. Therefore, it is important to maintain the company's profitability through Return on Equity (ROE) from the investor's perspective, not from the company's view. Meanwhile, interesting findings from a company's profitability through Earning per Share (EPS) do not affect the stock prices of food and beverage companies in Indonesia. Because earnings per share or earning per share (EPS) is obtained from the perspective of the company's financial statements where there are differences in the size and size of the company's expenses other than earning per share (EPS) can turn out to be high if the number of shares outstanding is reduced.
\end{abstract}

Keywords: Profitability, Return on Equity (ROE), Earnings per Share (EPS), Stock Prices, Indonesia stock exchange (IDX)

\section{INTRODUCTION}

The current global conditions make it relatively difficult for investors to make investment choices in the types of companies that provide many benefits to their shareholders. Companies that maximize profits show that the company has a correlation with corporate financial indicators such as Return on Equity (ROE) and Earning per Share (EPS). Therefore, company management can design and review the determination of strategies in order to improve the company's financial performance to show better financial indicators (Firdaus, 2020). Good financial indicators will be of interest to investors, especially investing in the Indonesian capital market, because they produce maximum profits (Kai et al., 2018). Therefore, it becomes an important factor in the company's 
The Effect Of Return on Equity (ROE) And Earning Per Share (EPS) on Stock Prices In Indonesia Stock Exchange 2015-2018

Lusiana

financial fundamentals. The issuer's financial statements can be seen the level of ability of the company's performance to generate profits and the ability of the company to pay debt and how effective and efficient the level of managing company wealth (Fakhri et al., 2020).

For measuring the financial health of a business firm, there are lots of techniques available. But the Altman's Z-score has been proven to be a reliable tool across the globe. This model devotes to predict possibilities of bankruptcy of manufacturing concerns. There is evidence that it has $76.9 \%$ accuracy in predicting the bankruptcy of the underlying sample (Begley et al. 1996). Altman (1968) defines five predicted factors that can be used to test the validity of Multivariate model. The model is based on financial ratios. Using financial ratios to predict bankruptcy can be accurate up to $90 \%$ (Chen \& Shemerda, 1981). Hence, this research aims to bankruptcy prediction using Altman z-Score model in retail trading company in Indonesian.

Return on equity (ROE) is a ratio used to measure net income after tax with their capital (Kasmir, 2015). Return on equity (ROE) can also show the power to the extent of generating investment returns based on the book value of shareholders. The higher the Return on Equity (ROE), the better, because the position of the owner of the company is getting stronger, so investors can measure the extent of the return on investment they have done (Asraf \& Desda, 2020). The results of empirical studies strengthen Return on equity (ROE) has an effect on stock prices, such as empirical studies (Lumingkewas, 2013); (Sanjaya, 2015); (Riani, 2016); (Sumaryanti, 2017); and (Nurlia \& Juwari, 2019). The interesting thing is that there are differences in findings that Return on Equity (ROE) has no effect on stock prices, such as empirical studies conducted (Aning Tyas \& Septa Saputra, 2016); (Susanto, 2016); (Zaky, 2016); (Sumaryanti, 2017); (Latifah \& Laila, 2017); (Utara, 2017); (Andry, 2017); (Amalya, 2018); (Winda Tristanti \& Sari Marliani, 2019); and (Prima \& Ismawati, 2019).

Furthermore, Earning Per Share (EPS) is a form of giving benefits to shareholders from each sheet owned (Fahmi, 2018). The existence of high profit giving to shareholders, then the demand for shares of the company will be high. the company's stock price, thereby encouraging investor interest to invest (Indriawati \& Nurfadillah, 2020). The results of empirical studies prove that Earning per Share (EPS) has an influence on stock prices, such as empirical studies (Marcellyna \& Hartini, 2011); (Choirani, 2013); (Muksal, 2015); (Yumia \& Khairunnisa, 2015); (Wicaksono, 2015); (Saryanti, 2015); (Mujiono, 2017); (Fajrian \& Sumawidjaja, 2018); (Lilianti, 2018); (Azmy, Ahmad; Lestari, 2019); (Alifiawan et al., 2019); and (Indriawati \& Nurfadillah, 2020). However, there are also contradictory findings that Earning per Share (EPS) does not have an effect on stock prices, such as empirical studies (Aning Tyas \& Septa Saputra, 2016); (Sumaryanti, 2017); and (Andry, 2017).

The research was conducted on 11 food and beverage companies listed on the Indonesia Stock Exchange (IDX) in 2015-2018. Fluctuating capital market conditions today are important because they have an impact on investment interest, even though the number of companies that register increases. The formulation of the problem is proposed based on the business phenomenon and the research gap phenomenon mentioned above, 1) Does Return on equity (ROE) affect stock prices; and 2) Do Earning Per Share (EPS) affect stock prices. While the research objective is to analyze the source of a company's profitability by choosing two main factors, namely, Return on Equity (ROE) and Earning per Share (EPS) as the strength and resilience of companies engaged in food and beverage listed on the Indonesia Stock Exchange. 
The Effect Of Return on Equity (ROE) And Earning Per Share (EPS) on Stock Prices In Indonesia Stock Exchange 2015-2018

Lusiana

\section{METHOD}

Table 1. Research Samples

\begin{tabular}{ccl}
\hline No & Company Code & \\
\hline 1. & ALTO & Tri Banyan Tirta Tbk \\
2. & DLTA & Delta Djakarta Tbk \\
3. & ICBP & Indofood CBP Sukses Makmur Tbk \\
4. & INDF & Indofood Sukses Makmur Tbk \\
5. & MLBI & Multi Bintang Indonesia Tbk \\
6. & MYOR & Mayora Indah Tbk \\
7. & PSDN & Prasidha Aneka Niaga Tbk \\
8. & ROTI & Nippon Indosari Corpindo Tbk \\
9. & SKLT & Sekar Laut Tbk \\
10. & STTP & Siantar Top Tbk \\
11. & ULTJ & Ultra Jaya Milk Industry Tbk \\
\hline
\end{tabular}

Source: Secondary data processed, 2020 (www.idx.co.id)

This research uses a descriptive method through a quantitative approach, with the reason that the research variable Return on Equity (ROE), Earning per Share (EPS) and Share Price focuses on the problem of novelty and the phenomena that occur at this time. Furthermore, the results of the study are explained in the form of numbers that have meaning. Return on Equity (ROE) with the symbol (X1) and Earning per Share (EPS) with the symbol (X2) are used as research independent variables. While the Stock Price with the symbol (Y) is used as the dependent variable of research. The data used in the form of secondary data, namely, the 2015-2018 financial statements that have been published by the Indonesia Stock Exchange.

The study population numbered 25 food and beverage companies listed on the Indonesia Stock Exchange in 2015-2018. Determination of the sample using purposive sampling, the sampling technique uses two criteria from researchers. The first criterion, only food and beverage companies that issue financial reports in full 2015-2018, and the second criterion, food and beverage companies that have financial report data in accordance with the studied variables, namely Return on Equity (ROE) and Earning per Share (EPS). So the samples that meet the criteria are 11 food and beverage companies listed on the Indonesia Stock Exchange 2015-2018. Data analysis techniques using multiple linear regression with the help of the SPSS program. The regression equation used is as follows:

$\mathrm{Y}=\alpha+\beta_{1} \mathrm{X}_{1}+\beta_{2} \mathrm{X}_{2}+\mathrm{e}$

$\mathrm{Y}$

A

$\mathrm{X}_{1}$

$\mathrm{X}_{2}$

$\beta_{1,} \beta_{2}$

$\mathrm{E}$

$$
\begin{aligned}
& =\text { Stock Prices } \\
& =\text { Constant } \\
& =\text { Return on Equity (ROE) } \\
& =\text { Earnings per Share (EPS) } \\
& =\text { Regression Coefficient } \\
& =\text { Error }
\end{aligned}
$$

The research consists of two hypotheses to be verified.

$\mathrm{H}_{1}=$ Return on Equity (ROE) has a significant positive effect on stock prices

$\mathrm{H}_{2}=$ Earnings per Share (EPS) has a significant negative effect on stock prices

The framework for this research is as follows:

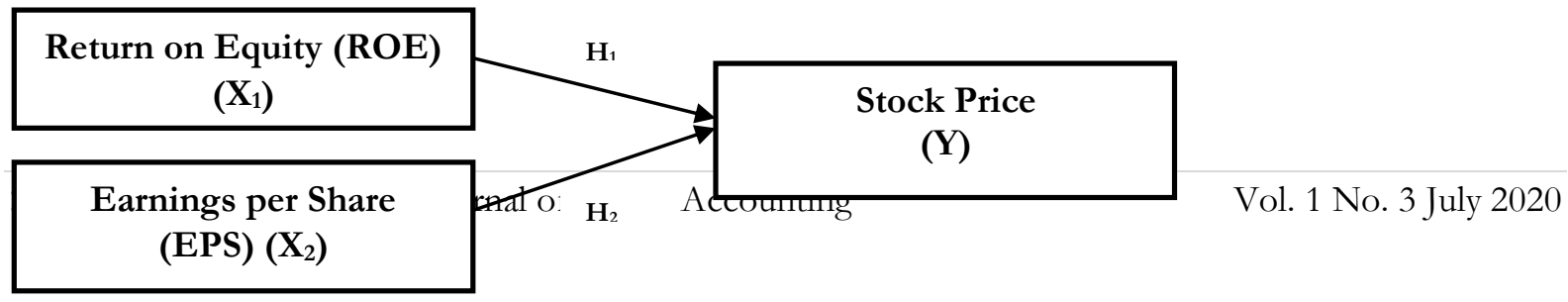


The Effect Of Return on Equity (ROE) And Earning Per Share (EPS) on Stock Prices In Indonesia Stock Exchange 2015-2018

Lusiana

Figure 1. Conceptual Framework

\section{RESULT AND DISCUSSION}

Table 1. Results of Regression Analysis Using SPSS Version 23

\begin{tabular}{lrrrrr}
\hline \multicolumn{1}{c}{ Variable } & $\begin{array}{l}\text { Regression } \\
\text { Coefficient }\end{array}$ & Beta & t-value & Sights & Information \\
\hline Constant (b0) & 818,425 & & & & \\
Return on Equity (X1) & 363,780 &, 805 & 6,504 &, 000 & Significant \\
Earnings per Share (X2) & $-27,232$ &,- 397 & $-3,209$ &, 003 & Significant \\
Adjusted R Square = 48,4\% & & & & & \\
$\mathrm{R}$ Square $=50,8 \%$ & & VIF $=1,278$ & \\
$\mathrm{R}=71,3$ & & ABS_RES X1=(Sig.) 0,061 & \\
$\mathrm{~F}$ value $=21,171$ & & ABS_RES X2=(Sig.) 0,095 & \\
Sig. F $=0,000$ & & & & \\
Asp. Sig. (2-tailed)=0,200 & & & &
\end{tabular}

Source: Data processed, 2020

Based on Table 1 above, that the multiple regression coefficients for the variables Return on Equity (ROE) $\left(\mathrm{X}_{1}\right)$ of 363.780 and a variable Earning per Share (EPS) $\left(\mathrm{X}_{2}\right)$ amounted to 27.232. So the regression equation is as follows:

$\mathrm{Y}=818,425+363,780 \mathrm{X}_{1}-27,232 \mathrm{X}_{2}$

The coefficient value $\left(\beta_{1}\right)$ amounts to 363,780 , if Return on Equity (ROE) $\left(\mathrm{X}_{1}\right)$ increases 1 percent, then it can be predicted that the stock price will increase by 363.780 percent with the assumption of other variables such as Earning per Share (EPS) fixed. Coefficient Return on Equity (ROE) p-value, the Return on Equity (ROE) has a positive effect on stock prices.

Value coefficient $\left(\beta_{2}\right)$ amounted to -27.232, if Earning per Share (EPS) (X2) increased 1 percent, then the stock price can be predicted to be down at 363.780 percent, assuming other variables such as Return On Equity (ROE) remained. The coefficient of Earning per Share (EPS) is negative, so the Earning per Share (EPS) has a negative influence on stock prices.

Based on the $t$ test results in Table 1. above, it can be seen that Return on Equity (ROE) $\left(\mathrm{X}_{1}\right)$ has a positive and significant effect on stock prices, because it has a significance value greater than 0.05 (Sig.0,000>0.05 ). Furthermore Earning per Share (EPS) $\left(\mathrm{X}_{2}\right)$ has a negative and significant effect on stock prices, because it has a significance value greater than 0.05 (Sig.0.003>0.05).

\section{Effect of Return on Equity (ROE) on Stock Prices}

The results of t-test Return on Equity (ROE) $\left(\mathrm{X}_{1}\right)$ have a positive and significant effect on stock prices that move on food and beverage companies on the Indonesia Stock Exchange can be proven or accepted. The findings show that Return on Equity (ROE) has a positive and significant impact on stock prices. If Return on Equity (ROE) $\left(\mathrm{X}_{1}\right)$ has increased, then it can be predicted that stock prices will increase. Return on equity (ROE) is a ratio used to measure net income after tax with their capital (Kasmir, 2015). The higher the Return on Equity (ROE), the better, because 
The Effect Of Return on Equity (ROE) And Earning Per Share (EPS) on Stock Prices In Indonesia Stock Exchange 2015-2018

Lusiana

the position of the owner of the company is getting stronger, so investors can measure the extent of the return on investment they have done (Asraf \& Desda, 2020)(Asraf \& Desda, 2020). This finding confirms that the strength of a company's profitability through Return on Equity (ROE) can affect the stock prices of food and beverage companies in Indonesia. Therefore, it is important to maintain the company's profitability through Return on Equity (ROE) whose substance is the investor's view, not the company's view. The findings of this study, strengthen the results of empirical studies conducted by (Lumingkewas, 2013); (Sanjaya, 2015); (Riani, 2016); (Sumaryanti, 2017); dan (Nurlia \& Juwari, 2019).

\section{Effect of Earning per Share (EPS) on Stock Prices}

Test results Earning per Share (EPS) $\left(\mathrm{X}_{2}\right)$ a significant negative effect on stock prices moving in the food and beverage company in Indonesia Stock Exchange can be proven or acceptable. Findings show that Earning per Share (EPS) has a negative and significant impact on stock prices. An interesting finding is that the profitability of a company through Earning per Share (EPS) does not affect the stock prices of food and beverage companies in Indonesia. Because earnings per share or earning per share (EPS) is obtained from the perspective of the company's financial statements where there are differences in the size and size of the company's expenses other than earning per share (EPS) can turn out to be high if the number of shares outstanding is reduced. Earnings Per Share (EPS) is a form of giving benefits to shareholders from each sheet owned (Fahmi, 2018). Given the high profits to shareholders, the demand for the company's shares will be high. The high demand for shares has an impact on increasing the company's stock price, thus encouraging investor interest to invest (Indriawati \& Nurfadillah, 2020). The findings of this study, strengthen the results of empirical studies conducted by (Aning Tyas \& Septa Saputra, 2016); (Khairani, 2016); (Sumaryanti, 2017); dan (Andry, 2017).

\section{CONCLUSION}

Return on Equity (ROE) has a positive and significant impact on stock prices. If Return on Equity (ROE) $\left(\mathrm{X}_{1}\right)$ has increased, then it can be predicted that stock prices will increase. The strength of a company's profitability through Return on Equity (ROE) can affect the stock prices of food and beverage companies in Indonesia. Therefore, it is important to maintain the company's profitability through Return on Equity (ROE) whose substance is the investor's view, not the company's view. Furthermore Earning per Share (EPS) does not affect the stock prices of food and beverage companies in Indonesia. Because earnings per share or earning per share (EPS) is obtained from the perspective of the company's financial statements where there are differences in the size and size of the company's expenses other than earning per share (EPS) can turn out to be high if the number of shares outstanding is reduced.

This study is limited to the effect of Return on Equity (ROE) and Earning per Share (EPS) on stock prices engaged in food and beverage companies listed on the Indonesia Stock Exchange. This study also has limited sampling in only 11 companies. It is hoped that further studies will take more samples so that research results can be generalized.

\section{REFERENCE}

Alifiawan, M. M., Ramadhan, A. M., \& Radianto, D. O. (2019). Pengaruh Fundamental dan Makro Ekonomi Terhadap Harga Saham Perusahaan Multi Nasional (Studi Kasus Perusahaan 
The Effect Of Return on Equity (ROE) And Earning Per Share (EPS) on Stock Prices In Indonesia Stock Exchange 2015-2018

Lusiana

Industri Dasar dan Kimia Tahun 2016 - 2017). Jurnal Ilmiah Tata Sejuta STIA Mataram, 5(1), 13-27. https://doi.org/10.32666/tatasejuta.v5i1.51

Amalya, N. T. (2018). Pengaruh Return On Asset, Return On Equity, Net Profit Margin Dan Debt To Equity Ratio Terhadap Harga Saham. Jurnal Sekuritas (Saham, Ekonomi, Kenangan dan Investasi), 1(3). https://doi.org/10.32493/skt.v1i3.1096

Andry. (2017). Pengaruh Earning Per Share, Return On Invesment dan Return On Equity terhadap Harga Saham pada Perusahaan Perdagangan. Jurnal Wira Ekonomi Mikroskil, 7(2), 209-218.

Aning Tyas, R., \& Septa Saputra, R. (2016). Analisis Pengaruh Profitabilitas Terhadap Harga Saham (Studi Kasus Perusahaan Telekomunikasi Yang Terdaftar di Bursa Efek Indonesia (BEI) Periode 2012-2014). Jurnal Online Insan Akuntan, 1(1), 77-91. https://www.neliti.com/id/publications/234092/analisis-pengaruh-profitabilitas-terhadapharga-saham-studi-kasus-perusahaan-tel

Asraf, A., \& Desda, M. M. (2020). Analysis of the Effect of Operating Leverage and Financial Leverage on Companies Profitability Listed on Indonesia Stock Exchange. Ilomata International Journal of Management, 1(2), 45-50.

Azmy, Ahmad; Lestari, A. (2019). Analisis Pengaruh Rasio Keuangan Terhadap Harga Saham Perusahaan RE \& Property di Indonesia. Jurnal Riset Manajemen Sains Indonesia (JRMSI), 10(2), 21. https://doi.org/10.21009/JRMSI.010.2.01

Choirani, G. (2013). Pengaruh Variabel Fundamental Internal Terhadap Harga Saham (Studi pada Saham LQ-45 yang Listing di BEI Periode Tahun 2009-2011). Jurnal Administrasi Bisnis S1 Universitas Brawijaya, 3(2), 74262.

Fahmi, F. (2018). Analisis Faktor-Faktor Fundamental Yang Berpengaruh Terhadap Return Saham Syariah Pada Perusahaan Yang Tergabung Dalam Jakarta Islamic Index (Jii). Eqien: Jurnal Ekonomi Dan Bisnis, 5(2), 18-36. https://doi.org/https://doi.org/10.34308/eqien.v5i2.58

Fajrian, F., \& Sumawidjaja, R. N. (2018). Analisis Debt To Equity Ratio, Earning Per Share, Return On Assets Dan Price Earning Ratio Terhadap Harga Saham.: Jurnal Riset Manajemen, 7(2), 59_ 68. https://doi.org/10.17509/image.v7i2.23135

Fakhri Rana Sausan, Lardin Korawijayanti, A. F. C. (2020). The Effect of Return on Asset (ROA), Debt to Equity Ratio (DER), Earning per Share (EPS), Total Asset Turnover (TATO) and Exchange Rate on Stock Return of Property and Real Estate Companies at Indonesia Stock Exchange Period 2012-2017. Ilomata International Journal of Tax and Accounting, 1(2), 103-114. https://www.ilomata.org/index.php/ijtc/article/view/66/59

Firdaus, F. (2020). Effect of Total Members and Current Ratio on the Rest of Cooperative Business Result. Ilomata International Journal of Management, 1(2), 38-44. https://www.ilomata.org/index.php/ijjm/article/view/64/42

Indriawati, I., \& Nurfadillah, M. (2020). Pengaruh Current Ratio Dan Earning Pershare Terhadap Harga Saham dengan Price Earning Ratio Sebagai Variabel Moderasi. Borneo Student Research (BSR), 1(2), 680-688.

Kai, K. De, Bin, I., \& Rahman, A. (2018). The Impact of Financial Indicators towards Stock Returns of Finance Companies Listed on Bursa Malaysiae. International Journal of Academic Research in Accounting, Finance and Management Sciences, 8(3), 128-140. https://doi.org/10.6007/IJARAFMS/v8-i3/4546

Kasmir, K. (2015). Analisis Laporan Keuangan. Jakarta: Rajawali Pers.

Khairani, I. (2016). Pengaruh Earning Per Share (EPS) dan Deviden Per Share terhadap Harga Saham Perusahaan Pertambangan yang Terdaftar di Bursa Efek Indonesia (BEI) Tahun 20112013. Jurnal Manajemen dan Keuangan Unsam, 5(2), 566-572.

Latifah, N. A., \& Laila, N. (2017). Pengaruh Return On Equity, Earning Per Share, dan Debt To Equity Ratio Terhadap Return Saham (Studi Pada Emiten Saham Syariah Sektor Property dan Real Estate yang Terdaftar di ISSI Tahun (2013 - 2015). Jurnal Ekonomi Syariah Teori Dan Terapan, 4(12), 1009-1023. https://doi.org/10.20473/vol4iss201712pp1009

Lilianti, E. (2018). Pengaruh Dividend Per Share (Dps) dan Earning Per Share (Eps) Terhadap 
The Effect Of Return on Equity (ROE) And Earning Per Share (EPS) on Stock Prices In Indonesia Stock Exchange 2015-2018

Lusiana

Harga Saham Pada Perusahaan Sub Sektor Farmasi di Bursa Efek Indonesia (BEI). Jurnal Ecoment Global, 3(1), 12. https://doi.org/10.35908/jeg.v3i1.353

Lumingkewas, C. (2013). Pengaruh Profitabilitas Terhadap Harga Saham. Journal of Business and Economic, 12(2), 225-233. https://doi.org/10.1017/CBO9781107415324.004

Marcellyna, F., \& Hartini, T. (2011). Pengaruh Earning Per Share (Eps) Terhadap Harga Saham Lq45 Di Bursa Efek Indonesia (Bei). Jurnal Akuntansi STIE MDP, 1-7.

Mujiono, H. P. (2017). Pengaruh CR, DER, ROA , dan EPS Terhadap Harga Saham Food and Beverages. Jurnal Imu Dan Riset Manajemen, 6(3), 1-17.

Muksal. (2015). Analisis Faktor-Faktor Yang Mempengaruhi Harga Saham Syariah. In Acta Universitatis Agriculturae et Silviculturae Mendelianae Brunensis (Vol. 16, Issue 1). https://doi.org/10.30798/makuiibf.323102

Nurlia, N., \& Juwari, J. (2019). Pengaruh Return On Asset, Return On Equity, Earning Per Share Dan Current Ratio Terhadap Harga Saham Pada Perusahaan Sub Sektor Otomotif Dan Komponen Yang Terdaftar Di Bursa Efek Indonesia. Jurnal GeoEkonomi, 10(1), 57-73. https://doi.org/10.36277/geoekonomi.v10i1.50

Prima, A., \& Ismawati, L. (2019). Pengaruh Perputaran Total Aset (Tato) Dan Tingkat Pengembalian Ekuitas (Roe) Terhadap Harga Saham Pada Perusahaan Sektor Tekstil Dan Garmen Yang Terdaftar di Bursa Efek Indonesia. Jurnal Ilmu Kenangan Dan Perbankan (IIKA), 8(1), 25-32. https://doi.org/10.34010/jika.v8i1.1926

Riani. (2016). Analisis Pengaruh Net Profit Margin, Return On Asset, dan Return On Equity Terhadap Harga Saham Perusahaan LQ45. Manajemen, 2(1), 78-107.

Sanjaya, T. (2015). Pengaruh Return,On Equity (Roe), Debt,Ratio (Dr), Debt To,Equity Ratio (Der), Earning,Per Share (Eps) Terhadap,Harga Saham (Studi pada,perusahaan Food,and Beverage yang,terdaftar di,Bursa Efek,Indonesia Periode 2011-2013). Jurnal Administrasi Bisnis S1 Universitas Brawijaya, 23(1), 85976.

Saryanti, E. (2015). Pengaruh Return on Equity Terhadap Harga Saham dengan Earning Per Share Sebagai Variabel Moderasi Pada Perusahaan Manufaktur di Bursa Efek Indonesia. Seminar Nasional Dan Call for Paper STIE “AUB,” 88-99.

Sumaryanti, T. N. (2017). Pengaruh ROA, EPS, NPM \& ROE Terhadap Harga Saham Perusahaan Sub-sektora Batu Bara yang Terdaftar di Bursa Efek Indonesia. eJournal Administrasi Bisnis, 5(2), 283-296.

Susanto, D. (2016). Pengaruh return on assets (ROA), return on equity (ROE), earning per share (EPS) terhadap harga saham pada PT Indocement tunggal prakasa, Tbk. dan entitas anak. Jurnal FinAcc.

Utara, A. (2017). Pengaruh return on asset (ROA), return on equity (ROE), earning per share (EPS), dan debt to equity eatio (DER) terhadap harga saham. Journal Universitas Dipenogoro, 112. https://ejournal3.undip.ac.id/index.php/jiab/article/view/16646/16017

Wicaksono, R. B. (2015). Pengaruh EPS, PER, DER, ROE dan MVA Terhadap Harga Saham. Jurnal Akuntansi, 5, 1-13.

Winda Tristanti, \& Sari Marliani. (2019). Pengaruh Return On Equity Dan Earning Per Share Terhadap Harga Saham Pada Perusahaan Manufaktur Sub Sektor Makanan Dan Minuman Yang Terdaftar Di Bursa Efek Indonesia Periode 2012 - 2017. BUANA ILMU, 4(1), 116136. https://doi.org/10.36805/bi.v4i1.813

Yumia, M. N., \& Khairunnisa. (2015). Pengaruh Return On Equity (ROE), Earning Per Share (EPS), dan Price Earning Ratio (PER) Terhadap Harga Saham Studi Kasus pada Perusahaan Pertambangan Logam dan Mineral Periode 2010-2014). E-Proceeding of Management, 2(3), 3179-3191.

Zaky, M. (2016). Pengaruh Analisis Fundamental Terhadap Harga Saham (Studi Empiris pada Saham Perusahaan Sement yang Terdaftar di Bursa Efek Indonesia Periode 2011 - 2014). Jurnal Ekonomak. https://doi.org/10.1192/bjp.205.1.76a 